\title{
Evaluation of cell biomarkers as in vitro photoprotective assays for sunscreen formulations
}

\author{
Sônia Aparecida Figueiredo ${ }^{1}$ (D), Fernanda Maria Pinto Vilela ${ }^{2}$ (D), Thaís Nunes dos Anjos ${ }^{1}$ (D), \\ Amanda Natalina Faria de Pádua ${ }^{3}$ (D), Maria José Vieira Fonseca1* (D) \\ Faculdade de Ciências Farmacêuticas de Ribeirão Preto, Universidade de São Paulo (USP), Ribeirão Preto, SP, Brasil \\ ${ }^{2}$ Faculdade de Farmácia, Universidade Federal de Juiz de Fora (UFJF), Juiz de Fora, MG, Brasil \\ ${ }^{3}$ Faria de Pádua Consultoria Técnico-Científica, Pouso Alegre, MG, Brasil \\ *Corresponding author: magika@fcfrp.usp.br
}

\begin{abstract}
Objectives: The aim of this study was to evaluate cellular indicators, which change with exposure to ultraviolet (UV) radiation and can be used as parameters for measuring sunscreens efficiency. Methods: Commercial strains of L929 and HaCaT cells (skin dermis and epidermis, respectively), from the cell bank of Rio de Janeiro, were exposed to different doses of UVA (350 nm) and UVB (309 nm) radiation. The evaluation of the photoprotective potential of sunscreens was analyzed with cell viability, lipid peroxidation and ROS generation tests. Samples of sunscreen with SPF values ranging from 15 to 60 were applied to a quartz plate superimposed on the top of a microplate containing the cell culture, and then the system was irradiated. Results: The viability and lipid peroxidation of the two cell lines remained unchanged after exposure to UVA radiation. When exposed to UVB radiation, the reduction in viability and the increase in lipid peroxides were dose-dependent, that is, they varied from 3.15\% to $95.4 \%$, and from 1.2 to $42.7 \mathrm{nM}$ MDA/pg protein, respectively, both for the $L 929$ strain. The dose of $0.5 \mathrm{~J} / \mathrm{cm}^{2}$ reduced by $41.4 \% \pm 1.67$ the number of viable cells, and the dose of $30 \mathrm{~J} / \mathrm{cm}^{2}$ promoted the oxidation of $42.7 \mathrm{nM}$ of MDA/pg protein. These doses were selected to evaluate the photoprotective effectiveness of commercial sunscreens. Sunscreens exposed to UVB rays could prevent the loss of cell viability (viability remained around $100 \%$ for higher SPF) and the formation of lipid peroxides (30 to $80 \%$ reduction of peroxide levels). None of the two cell strains, submitted to UVB radiation, formed amounts of intracellular ROS in a dosedependent manner. Under exposure to UVA radiation, only the HaCaT cell line produced the largest amounts of ROS in a dose-dependent manner. After treating these cells with photoprotective formulations $\left(20 \mathrm{~J} / \mathrm{cm}^{2}\right)$, the researchers observed a reduction in the amount of ROS formed. Conclusions: The parameters of cell viability and lipid peroxidation were promising to evaluate the photoprotective capacity of sunscreens against UVB radiation. The generation of ROS expressed in the HaCaT strain can discriminate the photoprotective potential of formulations against UVA radiation, as sunscreens reduced the formation of ROS. These results suggest that in vitro tests that evaluate the damage caused to cells can predict cellular indicators of the photoprotective effectiveness of sunscreens and contribute to minimize these tests in the initial phase of product research and development.
\end{abstract}

Keywords: Sunscreen. Photoprotective Effect. Cell Culture. Cellular Indicators. UV Radiation.

\section{How to cite}

Figueiredo SA, Vilela FMP, Anjos TN, Pádua ANF, Fonseca MJV. Evaluation of cell biomarkers as in vitro photoprotective assays for sunscreen formulations. Rev Ciênc Farm Básica Apl.

2021;42:e713. https://doi.org/10.4322/2179-443X.0713

Financial support: MVJF - Regular Research Grants from Fapesp (Fundação de Amparo à Pesquisa do Estado de São Paulo), SP, Process n 2013/16311-5. MJVF - MCTI/CNPQ/Universal from CNPq (Conselho Nacional de Desenvolvimento Científico e Tecnológico), Process n 481469/2013-3. SAF - Doctoral fellow from CNPq (Conselho Nacional de Desenvolvimento Científico e Tecnológico), Process n 159787/2013.

Conflicts of interest: The authors declare that there are no conflicts of interest regarding the publication of this article.

The study was carried out at Faculdade de Ciências Farmacêuticas de Ribeirão Preto, Universidade de São Paulo (USP),

Ribeirão Preto, SP, Brasil.

Received on November 17, 2020. Accepted on January 12, 2021. 


\section{INTRODUCTION}

Given the importance of photoprotection in public health, sunscreens have been used as one of the main preventive measures against the harmful effects of ultraviolet (UV) radiation ${ }^{1,2} .90 \%$ of nonmelanoma skin cancers and $86 \%$ of melanomas are caused by exposure to the sun and ultraviolet rays ${ }^{3}$, but the regular use of photoprotective formulations in the early stages of life (up to 18 years old) can reduce the incidence of skin cancer by $78 \%{ }^{4}$. In this sense, the application of sunscreen is strongly recommended by the World Health Organization and the scientific community ${ }^{5,6}$.

In general, sunscreen products are a combination of organic and inorganic filters. Organic filters absorb UV radiation and convert it to a harmless radiation to the skin (heat or light) ${ }^{4,7,8}$, and inorganic filters reduce UV radiation through physical mechanisms of reflection and dispersion ${ }^{4,7,9,10}$.

The protective efficiency of sunscreens has been mainly assessed in vivo using non-invasive methods, including UVB/UVA-2-induced erythema or sunburn, which is expressed as sun protection factor (SPF) and skin pigmentation, that is, immediate pigment darkening (IPD) and persistent pigment darkening (PPD) $)^{1,11-14}$.

However, studies have shown that considering only the in vivo erythema and pigment darkening responses to UV irradiation cannot adequately predict the deleterious effects of radiation on biological structures, immunosuppression, photoaging and carcinogenesis ${ }^{1,2,15-17}$.

To address these issues, this study evaluates some biological indicators that change with exposure to UV radiation and the photoprotective efficacy of sunscreen formulations to establish a complementary procedure to be used during product research and development.

We emphasize that the proposed use of these in vitro assays is not to replace the tests in humans but rather to optimize product development, guide the screening of the formulations and thereby reduce the number of formulations to be tested in vivo.

\section{METHODS}

\subsection{Sunscreen products}

For the in vitro assays, we selected commercial sunscreen products from two companies (A and B), from a local Brazilian market, which consist of a mixture of organic and inorganic filters. Brand A products were available with SPF values of 15, 30 and 60 in lotion form (Table 1). The labels claimed UVA + UVB protection, but the UVA protection was not expressed in PPD values.

According to the product labels, brand B sunscreen formulations had SPF values of 30,40 and 60 , and they differed from brand $A$ formulations by also providing PPD values (15, 25 and 41, respectively) (Table 1). The formulations with SPF/PPD 40/25 and 60/41 were also presented as lotions, while the product with SPF/PPD 30/15 was a cream formulation.

The presence of organic filters in sunscreen formulations of brands $A$ and $B$ was confirmed by high-performance liquid chromatography (HPLC). The extraction process consisted in using commercial samples sunscreens ( $20 \mathrm{mg}$ ) and a solvent mixture: $40 \mathrm{~mL}$ of methanol:water $(1: 1 \mathrm{v} / \mathrm{v})$ and $40 \mathrm{~mL}$ of dichloromethane for brand $\mathrm{A}$ products, and $40 \mathrm{~mL}$ of methanol:water $(1: 1 \mathrm{v} / \mathrm{v})$ and $80 \mathrm{~mL}$ of dichloromethane for brand $\mathrm{B}$ formulations. After manual dispersion of the mixtures and ultrasonic water bath for 20 minutes, the organic (dichloromethane) and aqueous (methanol and water) phases were obtained and subjected to chromatographic analysis. The recovery of these extraction processes were performed with the standard addition technique (organic filter Sigma-Aldrich, USA). $20 \mu \mathrm{L}$ of organic filters standards (Sigma-Aldrich, USA) and sample solutions were injected into the chromatographic system with the column and precolumn C18 Hypersil Gold (Thermo Fisher Scientific, USA). The elution 
was conducted with $0.8 \mathrm{~mL} \mathrm{~min}{ }^{-1}$ flow rate at $22^{\circ} \mathrm{C}$, with the following gradient program: (A) ethanol and (B) water with $1 \%$ formic acid - 0-5 $\min (55: 45), 5-15 \mathrm{~min}(60: 40), 15-20 \mathrm{~min}(80: 20)$, 20-35 min (100:0), 35-40 min (80:20), 40-45 $\min (60: 40), 45-50 \min (55: 45)$ and 50-51 $\min (9)$. Finally, monitoring was carried out at $313 \mathrm{~nm}$ (Chisvert et al. ${ }^{18}$ with modifications).

Table 1. Summary of organic and inorganic filters contained in commercial sunscreens (A and B) and their corresponding sun protective factor values.

\begin{tabular}{|c|c|c|c|c|c|}
\hline \multicolumn{3}{|c|}{ SUNSCREENS - BRAND A } & \multicolumn{3}{|c|}{ SUNSCREENS - BRAND B } \\
\hline SPF & $\begin{array}{c}\text { Organic/ inorganic } \\
\text { Filters }\end{array}$ & $\begin{array}{l}\text { UV absorption } \\
\text { region }\end{array}$ & SPF/PPD & $\begin{array}{c}\text { Organic/ } \\
\text { inorganic filters }\end{array}$ & UV absorption region \\
\hline & EHT & UVB, UVA-2 & & EHT & UVB, UVA-2 \\
\hline & OCT & UVB & & $\mathrm{OCT}$ & UVB \\
\hline & $\mathrm{TiO}_{2}$ * & UVB, UVA-2 & & $\mathrm{TiO}_{2} *$ & UVB, UVA-2 \\
\hline & BEMT & UVB, UVA-1/UVA-2 & & BEMT & UVB, UVA-1/UVA-2 UVB \\
\hline \multirow[t]{8}{*}{15} & & & $30 / 15$ & EHS & UVA-1, UVA-2 \\
\hline & & & & AVO & UVB \\
\hline & & & & HMS & UVB, UVA-1/UVA-2 UVA-1, UVA-2 \\
\hline & & & & DTS & \\
\hline & & & & TDSA & \\
\hline & EHT & UVB, UVA-2 & & EHT & UVB, UVA-2 \\
\hline & OCT & UVB & & OCT & UVB \\
\hline & $\mathrm{TiO}_{2}{ }^{*}$ & UVB, UVA-2 & & $\mathrm{TiO}_{2} *$ & UVB, UVA-2 \\
\hline \multirow[t]{7}{*}{30} & BEMT & $\begin{array}{c}\text { UVB, UVA-1/UVA-2 } \\
\text { UVA-1, UVA-2 }\end{array}$ & $40 / 25$ & BEMT & UVB, UVA-1/UVA-2 UVA-1, UVA-2 \\
\hline & AVO & & & AVO & UVB, UVA-1/UVA-2 UVA-1, UVA-2 \\
\hline & & & & DTS & \\
\hline & & & & TDSA & \\
\hline & EHT & UVB, UVA-2 & & EHT & UVB, UVA-2 \\
\hline & OCT & UVB & & OCT & UVB \\
\hline & $\mathrm{TiO}_{2}^{*}$ & UVB, UVA-2 & & $\mathrm{TiO}_{2} *$ & UVB, UVA-2 \\
\hline \multirow[t]{4}{*}{60} & BEMT & $\begin{array}{c}\text { UVB, UVA-1/UVA-2 } \\
\text { UVB }\end{array}$ & $60 / 41$ & BEMT & UVB, UVA-1/UVA-2 UVA-1, UVA-2 \\
\hline & EHS & UVA-1, UVA-2 & & AVO & UVB, UVA-1/UVA-2 UVA-1, UVA-2 \\
\hline & AVO & & & DTS & \\
\hline & & & & TDSA & \\
\hline
\end{tabular}

SPF: Sun Protection Factor; PPD: Persistent Pigment Darkening. EHT: Ethylhexyl triazone; OCT: Octocrylene; $\mathrm{TiO}_{2}{ }^{*}$ : Titanium dioxide; BEMT: Bis-ethylhexyloxyphenol methoxyphenyl triazone; EHS: Ethylhexyl salicylate; AVO: Avobenzone; HMS: Homosalate; DTS: Drometrizole trisiloxane; TDSA: Terephthalydene dicamphor sulfonic acid. *Inorganic filter

\subsection{Development of in vitro assays for assessing the photoprotective potential of sunscreen formulations}

\subsubsection{Cell culture and irradiation}

Cell lines L929 (fibroblast cells) and HaCaT (keratinocytes cells) were acquired from the Rio de Janeiro Cell Bank (RJCB). These are cells types present in the human skin layers, and considered a basic in vitro model for assessing biological effects induced by UV in skin ${ }^{19}$. The cells were grown in DMEM (Dulbecco's modified Eagle's medium, Gibco ${ }^{\circledR}$, Mandaluyong, Philippines), supplemented with a fetal bovine serum (10\%) solution (FBS, Gibco ${ }^{\circledR}$, Mandaluyong, Philippines), penicillin (100 U/mL, Sigma-Aldrich, Saint Louis, USA), streptomycin $(0.10 \mathrm{mg} / \mathrm{mL}$, Sigma-Aldrich, Saint Louis, USA) and amphotericin B $(0.25 \mathrm{mg} / \mathrm{mL}$, Sigma-Aldrich, Saint Louis, USA). The cultures were maintained in an incubator at $37^{\circ} \mathrm{C}$ in a $5 \%$ $\mathrm{CO}_{2}$ atmosphere ${ }^{20}$. 
For irradiation, $\mathrm{L} 929$ or HaCaT cells were seeded into 6-well microplates at a confluence of $8 \times 10^{5}$ cells/well and maintained in the incubator for 12 hours. After incubation, the culture medium was replaced with $2 \mathrm{~mL}$ of Hank's balanced salt solution (HBSS). The microplates were covered with a quartz slide, under which $2 \mathrm{mg} / \mathrm{cm}^{2}$ of the sunscreens samples were applied and submitted to UV radiation ${ }^{1,20}$. The Bio-Espectra-3 system (Vilber Lourmat, Marne-La-Vallée, France) was used as a radiation source, with UVA lamps (maximum peak at $350 \mathrm{~nm}$ ) and UVB lamps (maximum peak at $309 \mathrm{~nm}$ ). This irradiation system includes a silicon photoelectric sensor for monitoring the emitted dose, the scheduled irradiation time/dose and an internal ventilation system to prevent overheating - the temperature did not exceed $30^{\circ} \mathrm{C}$.

\subsubsection{Cell viability}

Cell viability was evaluated in $\mathrm{L} 929$ and $\mathrm{HaCaT}$ cells, exposing them to different doses of UVA $\left(25 \mathrm{~J} / \mathrm{cm}^{2}\right.$ or $\left.30 \mathrm{~J} / \mathrm{cm}^{2}\right)$ and UVB $\left(0.05 \mathrm{~J} / \mathrm{cm}^{2}\right.$ or $\left.20.00 \mathrm{~J} / \mathrm{cm}^{2}\right)$ radiation. After this process, carried out according to procedure 2.2.1, the Hank's buffer was removed and replaced with $2 \mathrm{~mL}$ of DMEM (containing 2\% FBS). The microplates were then put again in a incubator at $37^{\circ} \mathrm{C}$ with $5 \% \mathrm{CO}_{2}^{21}$. After 48 hours, the cells were washed with saline, and $200 \mu \mathrm{L}$ of an aqueous solution of $0.01 \%$ resazurin was added to $2 \mathrm{~mL}$ of the culture medium supplemented with $10 \%$ FBS. The microplates were then incubated at $37^{\circ} \mathrm{C}$ for 4 hours. Thereafter, the fluorescence was measured in fluorimeter plates (BioTek Synergy 2, BioTek Instruments Inc., USA) with an excitation wavelength of $540 \mathrm{~nm}$ and emission of $590 \mathrm{~nm}^{22}$. The percent viability of the protected and irradiated cells was determined considering a $100 \%$ viability of the non-irradiated/not protected cells (control group). The experiments were conducted in triplicate on different days $(n=9)$.

\subsubsection{Lipid peroxidation}

Lipid peroxidation was assessed by exposing L929 and HaCaT cells to different doses of UVA ( 1 to $80 \mathrm{~J} / \mathrm{cm}^{2}$ ) and UVB (1 to $40 \mathrm{~J} / \mathrm{cm}^{2}$ ) radiation. After UV exposure, the cells culture irradiated in Hank's buffer were detached by scraping the microplate with a plastic support (cell scraper, TPP ${ }^{\circledR}$ ), thereby yielding a cell suspension, which was frozen at $-20^{\circ} \mathrm{C}$. On the day of the experiment, the suspension was thawed at $40^{\circ} \mathrm{C}$ and lysed in three cycles of freezing in liquid nitrogen and thawing at $40^{\circ} \mathrm{C}$. A portion of the lysed cell suspension was stored for protein determination with the Bradford method ${ }^{23}$. Samples of $900 \mu \mathrm{L}$ of each lysed cell suspension were transferred to test tubes, and we added $1 \mathrm{~mL}$ of a $0.375 \%$ TBA solution $(\mathrm{w} / \mathrm{v})$ in $0.250 \mathrm{M}$ hydrochloric acid containing $15 \%$ trichloroacetic acid $(\mathrm{w} / \mathrm{v})$. The mixture was then heated at $80^{\circ} \mathrm{C}$ for $15 \mathrm{~min}$ and cooled on ice. Then, $2 \mathrm{~mL}$ of $\mathrm{n}$-butanol was added to the mixture to extract the MDA-TBA complex formed. After agitation and centrifugation of the mixture, the organic phase was collected and subjected to fluorescence spectrophotometry at an excitation wavelength of $515 \mathrm{~nm}$ and emission wavelength of $550 \mathrm{~nm}$ (BioTek Synergy 2 - Multimode microplate reader, BioTek Instruments Inc., USA ${ }^{24}$.

The results are expressed as the percentage of MDA/TBA produced, and a standard curve was prepared using tetraethoxypropane, which quantitatively releases the thiobarbituric acidmalondialdehyde adducts under experimental conditions ${ }^{24}$. Each determination was performed on three different days in triplicate $(n=9)$.

\subsubsection{Cellular oxidant stress}

L929 and HaCaT cells were exposed to UVB (0.1 to $\left.20.0 \mathrm{~J} / \mathrm{cm}^{2}\right)$ and UVA $\left(0.25\right.$ to $\left.40.00 \mathrm{~J} / \mathrm{cm}^{2}\right)$ radiation, and the fluorescence signal generated by $\mathrm{DCFH}_{2}$-DA (Sigma-Aldrich, Saint Louis, USA) was measured.

Before being irradiated, the cell cultures were incubated with Hank's buffer solution containing $5 \mu \mathrm{M} \mathrm{DCFH}{ }_{2}$-DA (2',7'-dichlorodihydrofluorescein diacetate, Sigma-Aldrich, Saint 
Louis, USA) for 30 minutes $^{25}$. Then the cells were washed with a saline solution followed by the addition of $2 \mathrm{~mL}$ of Hank's buffer solution and subjected to UVB and UVA radiation. After irradiation, the intensity of fluorescence was measured using a BioTek Synergy 2 multi-mode microplate reader (BioTek Instruments Inc., USA) at an excitation wavelength of $485 \mathrm{~nm}$ and emission wavelength of $528 \mathrm{~nm}^{26}$. The experiments were conducted in triplicate on three different days $(n=9)$.

\subsubsection{Validation of the in vitro assays}

The validation of in vitro assays was based on selectivity and inter-day precision parameters according to the standards of the International Conference on Harmonization (ICH) for certification of analytical procedures ${ }^{27}$.

The selectivity parameter was applied to analyze whether the cell viability and cell oxidative stress tests could be used to evaluate the photoprotective efficacy of products exposed to UVB and UVA radiation, respectively. For this, two compounds were tested: UVB radiation absorber (Garcinia brasiliensis extract) in concentrations of 2\%, 5\% and 10\%, and UVA radiation absorber (astaxanthin) in concentrations of $2 \%$ and $5 \%$.

The ethanolic extract of Garcinia brasiliensis was supplied by PhD Marcelo Henrique dos Santos from Federal University of Viçosa (MG, Brazil), and the natural product astaxanthin was kindly provided by Galena ${ }^{\circledR}$.

The inter-day precision of the photoprotective efficacy assays (cell viability, lipid peroxidation and cell oxidative stress) was expressed as the percentage of relative standard deviation (DPR, \%). The measurements were made in triplicate for three consecutive days, using cell cultures with different passages in the cell growth cycle (between the 3rd and 8th passages).

\subsubsection{Statistical analysis}

Data analysis was performed using OriginPro 7.0 software (OriginLab Corporation, USA). To analyze the in vitro assays results, the one-way ANOVA statistical test was applied followed by the Tukey's comparison test. $\mathrm{P}$ values $<0.05$ showed statistical difference among the treatments (sunscreens) and controls (NIC - negative control, and IC - positive control) at the $95 \%$ confidence interval.

\section{RESULTS AND DISCUSSION}

\subsection{HPLC analysis of organic filters}

The procedure for the extraction of organic filters in the sunscreens was validated by the recovery method through standard addition. The results showed that the percent recovery ranged from $93.05 \%$ to $101.55 \%$ for brand $\mathrm{A}$ and $73.85 \%$ to $93.20 \%$ for brand $\mathrm{B}$. These are acceptable values, according to Sabater-Tobella and Vilumara-Torrallardona ${ }^{28}$.

Qualitative analysis of the sunscreens using HPLC confirmed the composition of all organic filters indicated on their labels (Figure 1A and 1B). These filters were identified by comparing the retention times of standards and chromatographic data obtained by Chisvert et al. ${ }^{18}$ and Moreta and Tena ${ }^{29}$. We detected no chromatographic peaks in the aqueous phase from the extraction procedure for brand A, suggesting that these products do not contain water-soluble organic filters. On the other hand, in the aqueous phase obtained from the extraction of brand B products, the TDSA filter was detected, confirming the presence of the single water-soluble UV filter indicated on the packaging of these sunscreens. 
(A)
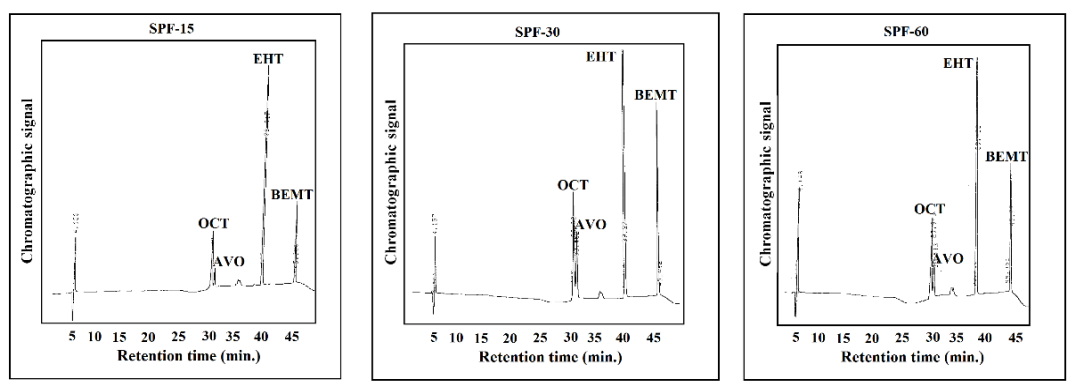

(B)
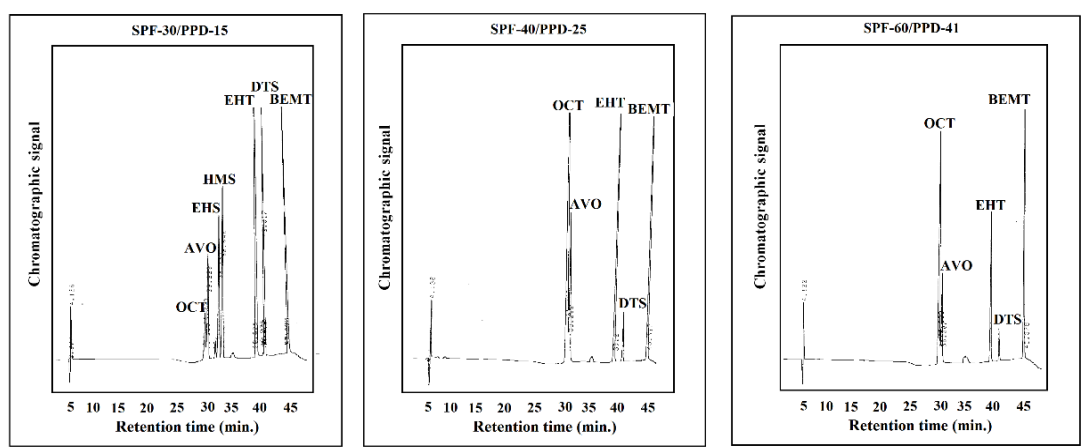

Figure 1. Chromatographic profiles of organic UV filters present in commercial sunscreens obtained from the qualitative analysis by HPLC. (A) Brand A with sun protection factors (SPF) of 15, 30 and 60 and (B) Brand B with SPF of 30, 40 and 60 and Persistent Pigment Darkening (PPD) of 15, 25 and 41. OTC = Octocrylene; $A V O=$ Avobenzone; EHT = Ethylhexyl triazone; BEMT = bis-ethylhexyloxyphenol methoxyphenyl triazone; $\mathrm{HMS}=$ Homosalate; EHS = Ethylhexyl salicylate; DTS = Drometrizole trisiloxane.

\subsection{Cell culture and irradiation}

UV radiation causes cellular and molecular damage to nucleic acids, proteins and lipids and also changes in cell functions. This exposure to UV rays involves two skin compartments (epidermis and dermis) $^{30,31}$. UVB rays are the most energetic UV wavelengths and can directly induced DNA lesions resulting in the activation of mechanisms of cell death. UVA radiations are less energetic than UVB, but have higher penetration properties. Their major mode of action is the generation of reactive oxygen species (ROS) $)^{7,30}$. Thus, the tests of cell viability, lipid peroxidation and cell oxidative stress in vitro were selected for reflecting these changes and can be easily performed in the laboratory.

The biological responses using in vitro assays based on cell culture were first assessed using various levels of UV radiation exposure to establish the best model. Secondly, these assays were assessed using two brands of sunscreen ( $A$ and $B$ ) that differed in the composition of organic UV filters and excipients/vehicles. Finally, the selectivity and precision of the culture model were validated.

To select the irradiation dose of the cells, a dose versus response curve was constructed for each cell type and for each biological parameter tested. The selected dose was the one that induced a response difference of approximately $50 \%$ between the irradiated and nonirradiated cells.

\subsection{Cell viability}

Exposing the skin to certain substances causes morphological, structural, and functional changes, and even the death of cells. Therefore, cell viability tests allow researchers to quantify and monitor the harmful effects of such exposure ${ }^{32}$.

Among the doses of UVA radiation tested, no dose reduced the cell viability of L929 and HaCaT skin lines. 
Although UVB radiation is absorbed predominantly by cells of the upper layer of skin (epidermis), in our study L929 cell line showed a stronger response after UVB exposure than $\mathrm{HaCaT}$ keratinocyte cells ${ }^{33}$. Gęgotek et al. ${ }^{34}$ also found a greater response in fibroblasts than in keratinocytes. According to Battie et al..$^{33}$ and Zeng et al. ${ }^{25}$, approximately 10 to $30 \%$ of UVB radiation can penetrate the epidermis to reach the upper layers of the dermis, thus harming the fibroblasts and generating severe oxidative stress.

The selected UVB radiation dose $\left(0.5 \mathrm{~J} / \mathrm{cm}^{2}\right)$ induced a $41.40 \pm 1.67 \%$ reduction in cell viability. According to Figueiredo et al.17, a dose of UVB radiation that reduces the number of viable cells by approximately $50 \%$ is appropriate for the evaluation of the photoprotective potential of plant extracts.

The results showed that both brand A and brand B sunscreens could protect $L 929$ cells against the loss of viability induced by UVB radiation (Figure 2). Brand B sunscreens offered greater protection against cell viability loss induced by UVB radiation than brand A products. The brand B product with an SPF/PPD of 30/15 improved the cell viability by $28.9 \pm 5.6 \%$ in relation to the irradiated control (IC), and the viability of the cells treated with the products with SPFs/PPDs of 40/25 and 60/41 was statistically similar to non-irradiated control (NIC) (Figure 2).

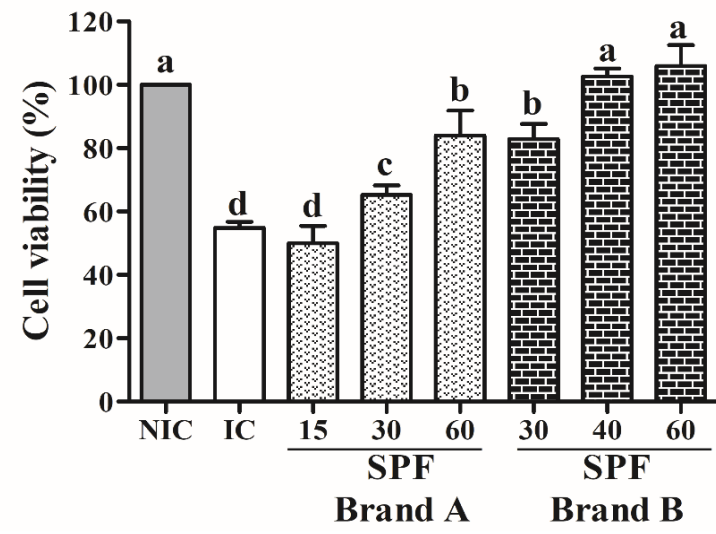

Figure 2. Measurement of the viability of L929 cells exposed or not to UVB radiation $\left(0.5 \mathrm{~J} / \mathrm{cm}^{2}\right)$ under sunscreen protection or not. The brand A sunscreens with SPF-15, SPF-30 and SPF-60 and brand B sunscreens with SPF-30/PPD-15, SPF-40/PPD-25 and SPF-60/PPD-41. NIC = Non-irradiated control and IC $=$ irradiated control. The results represent the average of three independent experiments with $n=9$. Different letters indicate that there was a statistically significant difference after analysis by the oneway ANOVA test followed by the Tukey test for multiple comparisons $(p<0.05)$.

This test allowed the observation of different protection levels provided by sunscreens with the same and different SPFs. Although sunscreens of both brands have SPF-30, brand B has more filters that absorb wavelengths of the UVB region (EHS, HMS and DTS) than brand A, resulting in greater photoprotective efficiency. SPF- 40 and SPF- 60 of brand $B$ products were more efficient than the those of brand A, with SPF-30 and SPF-60. Brand B sunscreens have an additional UVB absorber filter in their composition (DTS). The literature shows that high SPF and wide spectrum protectors, as is the case of brand B, can protect against multiple damage in cell-level biomarkers ${ }^{35}$.

\subsection{Lipid peroxidation}

Lipid peroxidation begins with the capture of electrons from unsaturated fatty acids of cell membrane phospholipids by reactive oxygen species (ROS). Chain reactions lead to lipid degradation and the formation of aldehyde products, such as malondialdehyde (MDA). Approximately $40 \%$ of the cellular membrane is lipid and the composition of lipids differs in the membranes present in the cell. The concentrations of sterols and sphingolipids increase 
from endoplasmic reticulum to the cell surface ${ }^{36,37}$. Therefore, to assess the ability of sunscreens to photoprotect cell membranes from lipid peroxidation induced by ultraviolet radiation, we selected L929 and HaCaT cells as a source of lipids.

The reaction of MDA with thiobarbituric acid (TBA) to produce a pink colored dimeric compound was used to measure lipid peroxidation due to the ease of the reaction combined with the simplicity of using fluorescence spectrophotometry to quantify the pink adduct.

Both cells lines were exposed to various doses of UVA and UVB radiation. The results showed that under the tested doses of UVA radiation, the MDA/TBA production obtained negative values after normalization with cellular protein content. These results differ from those published in the literature. This may be due to the source of UVA radiation used. Currently, metal-doped, fluorescent and xenon lamps have been used in laboratory tests. They provide variable results due to the spectral differences of each lamp and the interaction with the spectral qualities of the sunscreens tested ${ }^{38}$.

On the other hand, doses of UVB radiation ranging from 1 to $40 \mathrm{~J} / \mathrm{cm}^{2}$ induced lipid peroxidation in both cell lines, with the greatest amount of MDA/TBA being detected in L929 cells (Figure 3A and 3B). This higher amount of MDA/TBA production may be related to higher ROS generation (Figure 3D). Thus, excessive exposure to UVB radiation leads to oxidative stress that increases the generation of reactive oxygen species (ROS), resulting in damages to lipid peroxidation of cell membranes ${ }^{39}$.
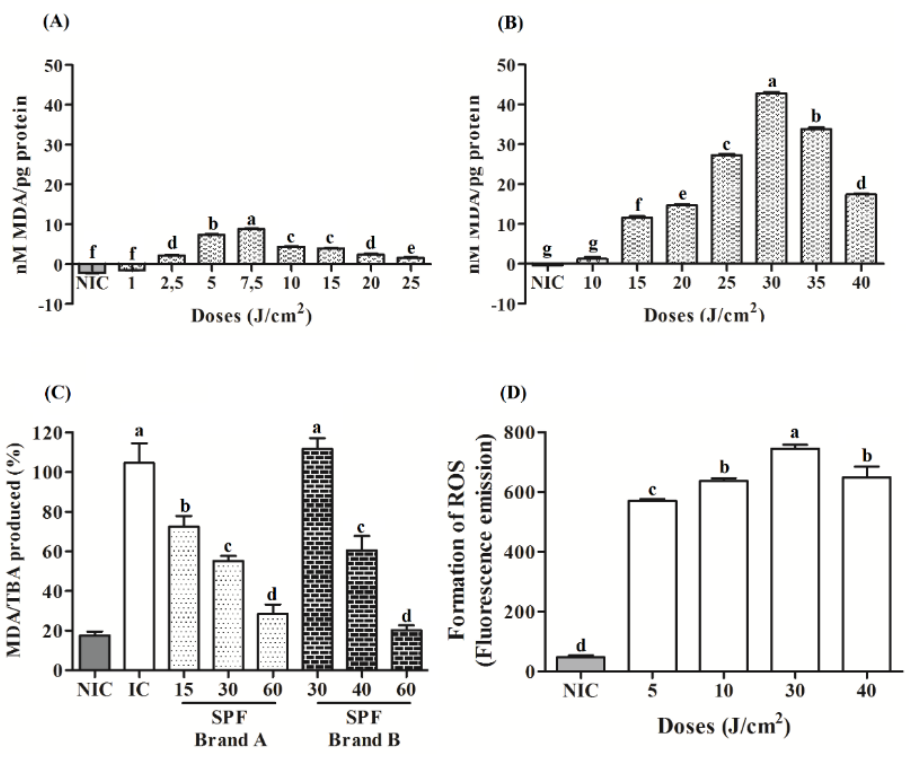

Figure 3. Lipid peroxidation measured based on the formation of malondialdehyde- thiobarbituric acid (MDA/TBA) complexes after UVB radiation. A) Curve dose-response of the HaCaT strain. B) Curve doseresponse of the L929 strain. C) Treatment of the L929 cells with commercial brand A sunscreens with SPF-15, SPF-30 and SPF-60 and brand B with SPF-30/PPD-15, SPF-40/PPD-25 and SPF-60/PPD-41 under

$30 \mathrm{~J} / \mathrm{cm}^{2}$ UVB radiation. D) Curve dose-response of quantification of ROS formed in L929 cells as measured with the fluorescence probe $\mathrm{DCFH}_{2}-\mathrm{DA}$ after UVB radiation. NIC = Non-irradiated control, and IC = irradiated control. The results represent the average of three independent determinations with $\mathrm{n}=9$. Different letters indicate that there was a statistically significant difference after analysis by the one-way ANOVA test followed by the Tukey test for multiple comparisons $(p<0.05)$.

An increase in the amount of MDA/TBA was observed up to a dose of $30 \mathrm{~J} / \mathrm{cm}^{2} \mathrm{UVB}$, although at higher doses, decreases in the amount of aldehyde were detected (Figure 3B). This result may be due to the formation of various mutagenic adducts between MDA and DNA. The most prominent adduct results from the reaction with guanine residues and is considered 
to be the most mutagenic to cells underoxidative stress conditions. MDA can also bind to lysine residues of proteins and to a lesser extent to histidine, tyrosine, arginine and methionine residues ${ }^{40-42}$.

$30 \mathrm{~J} / \mathrm{cm}^{2}$ of UVB radiation allowed to visualize differences in the MDA/TBA production between brand $A$ and $B$ sunscreens. Therefore, the lipids from $L 929$ cell line exposed at a dose of $30 \mathrm{~J} / \mathrm{cm}^{2}$ of UVB was used to evaluate the efficacy of commercial sunscreens against lipid peroxidation. Karthikeyan et al. ${ }^{43}$ also showed a significant induction of lipid peroxidation in fibroblast cells.

The results clearly showed that in vitro lipid peroxidation was a very interesting parameter for the evaluation of the sunscreens efficacy with various SPF values against UVB radiation. We found a significant increase in the MDA/TBA production after exposure of the untreated cells to UVB radiation compared to the non-irradiated group (Figure 3C).

In addition, the results showed that treatment of the cells with the commercial sunscreens of brands A and B can protect the cells against lipid peroxidation. Interestingly, for both brands, there was a relationship between the SPF values and the protection provided, as demonstrated by the greater protection conferred by the higher SPF (Figure 3C).

The brand B sunscreen, with SPF-30 and PPD-15, was the only product among all those analyzed that did not protect the cells against the lipid peroxidation induced by UVB radiation. UV filters can be unstable after UV radiation absorption ${ }^{44}$. Therefore, the concept of photostability is very important for evaluating solar protection. Couteau et al. ${ }^{45}$ analyzed the photostability of various photoprotectors agents incorporated into cream formulations and they observed the photodegradation of UV filters, such as HMS, BEMT and EHT. The photoprotective product with SPF-30 and PPD-15 also has in its composition those UV filters, and it was a cream form, whereas all of the others anti-solar products were lotions. The variability of excipients also may have affected the quality and functionality of the product ${ }^{46}$.

Based on the photoprotection results obtained in relation to the rapidity, ease and reproducibility of the assay, the measurement of percentage decrease in the amount of MDA generated by $L 929$ cells could be used to choose UV filters, the combinations between different UV filters and the most suitable vehicle during the development of new photoprotective formulations, prior to testing in humans, in order to determine SPF.

\subsection{Cellular oxidant stress}

UV radiation induces oxidative stress and stimulates the production of ROS, which cause damage to DNA, proteins and cell organelles, inducing changes in cellular structures and functions, in addition to lipid peroxidation and apoptosis ${ }^{47-49}$. Intracellular ROS can be determined using probes capable of responding to the presence of these species in a quantifiable manner. The mechanism of interaction between ROS and the probes may involve oxidation-reduction reactions $\mathrm{s}^{50}$. Techniques using fluorescent probes are very sensitive - the most commonly employed probes are fluorescein and dichlorofluorescein, due to their stability and low reactivity 47,50 .

The 2',7'-dichorodihydrofluorescein assay was used as a measurement method for fluorescent cellular oxidant stress in cell cultures exposed to UV rays ${ }^{51}$. L929 and HaCaT cells were treated with the $\mathrm{DCFH}_{2}$-DA solution (fluorescent probe) and exposed to various doses of UVB radiation $\left(0.1\right.$ to $\left.20.0 \mathrm{~J} / \mathrm{cm}^{2}\right)$. However, the radiation dose required to generate the fluorescence $\left(>5 \mathrm{~J} / \mathrm{cm}^{2}\right)$ reduced cell viability. Therefore, the photoprotective efficacy of sunscreens against $D C F H_{2}$-DA oxidation by UVB radiation was not evaluated.

Both cell lines were also tested under various doses of UVA $\left(0.25\right.$ to $\left.20.00 \mathrm{~J} / \mathrm{cm}^{2}\right)$. HaCaT cell line was chosen for having generated a greater amount of fluorescence due to the dosedependent oxidation of the $\mathrm{DCFH}_{2}$-DA probe (Figure $4 \mathrm{~A}$ ). The radiation dose of $20 \mathrm{~J} / \mathrm{cm}^{2}$ of UVA was selected since it could oxidize the $\mathrm{DCFH}_{2}$-DA probe and did not induce viability loss of $\mathrm{HaCaT}$ cells. The dose is related to the one obtained by the solar spectrum in a 3h30minperiod. We calculated it after measuring the average UVA radiation emitted by the sun on two days of October between 11 am and 2:30 pm in the city of Ribeirão Preto, SP, Brazil, using the 
same radiometer used in the studies. The temperature on these days reached $38^{\circ} \mathrm{C}$ Marionnet et al.26 observed and quantified the induction of ROS in reconstructed skin treated with the DCFH 2 -DA probe followed by exposure to UVA-1 $\left(10 \mathrm{~J} / \mathrm{cm}^{2}-40 \mathrm{~J} / \mathrm{cm}^{2}\right)$.

The oxidation of the probe within HaCaT cells by UVA radiation led to increased fluorescence compared to non-irradiated cells. When the cells were protected against UVA radiation by the commercial sunscreens $A$ and $B$, the fluorescence generated by the oxidation of the probe was lower than that generated by unprotected irradiated cells. All sunscreen products effectively protected $\mathrm{HaCaT}$ cells againstDCFH $\mathrm{H}_{2}$-DA oxidation (Figure 4B).

The efficiency of the brand B products was directly proportional to PPD: lower values of PPD resulted in lower photoprotective efficiency, and higher values of fluorescence resulted in higher photoprotective efficiency (Figure 4B). This correlation was not observed for brand A products. In this case, no significant difference in the emitted fluorescence between the cells protected with SPF-15 and SPF-30 products was observed, which indicated the same photoprotective efficacy (Figure 4B).
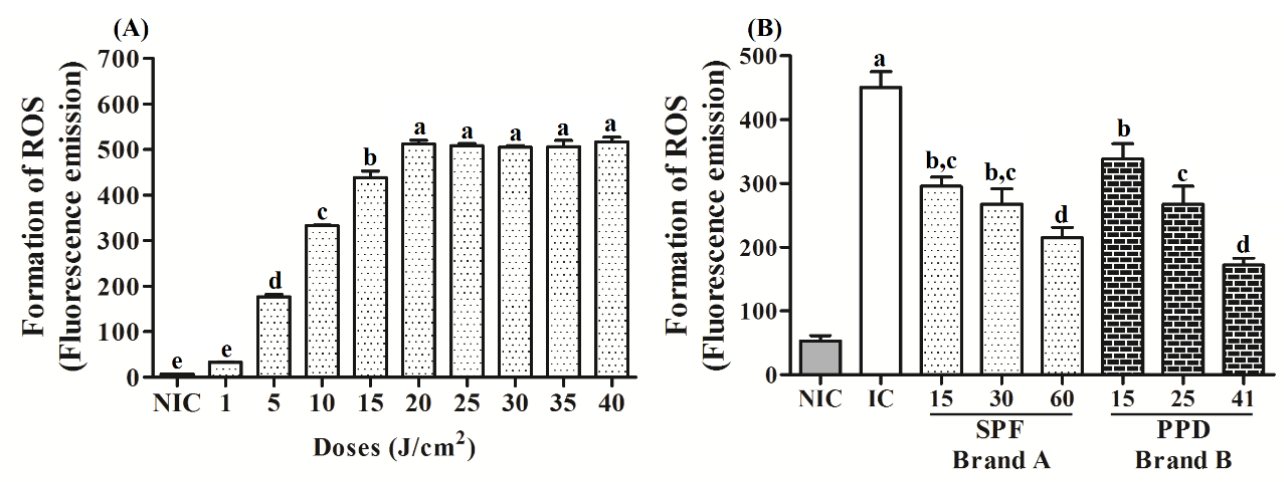

Figure 4. Quantification of ROS as measured with the fluorescence probe $\mathrm{DCFH}_{2}$-DA after UVA radiation $\left(20 \mathrm{~J} / \mathrm{cm}^{2}\right)$. A) Curve dose-response of the $\mathrm{HaCaT}$ strain. B) The HaCaT cells were treated with commercial brand A sunscreens with SPF-15, SPF-30 and SPF-60 and brand B with SPF-30/PPD-15, SPF40/PPD-25 and SPF-60/PPD-41. NIC = Non-irradiated control, and IC = irradiated control. The results represent the average of three independent determinations with $n=9$. Different letters indicate that there was a statistically significant difference after analysis by the one-way ANOVA test followed by the Tukey test for multiple comparisons $(p<0.05)$.

This assay confirmed that products with UVA-1 and UVA-2 absorbed filters can provide protection against oxidative stress such as ROS generation, which shows the need to evaluate new biomarkers related to the deleterious effects of UVA radiation on the skin. This assay proved to be a biological marker that can complement the tests carried out during the development phase of new products acting as screening in the selection of combinations of UV filters to be incorporated in sunscreens.

\subsection{Validation of in vitro assays}

All concentrations (2\%, $5 \%$ and $10 \%$ ) of the Garcinia brasiliensis extract, a UVB absorber, could prevent the reduction in the cell viability of $L 929$ fibroblast cells exposed to $0.5 \mathrm{~J} / \mathrm{cm}^{2}$ of UVB radiation in a concentration-dependent manner (Figure 4A). On the other hand, astaxanthin, which does not absorb in the UVB region, could not prevent the cell viability loss of L929 cells exposed to UVB radiation in the tested concentrations of $0.06 \%$ and $0.15 \%$ (Figure $5 \mathrm{~A}$ ).

Under UVA radiation, none of the concentrations of $G$. brasiliensis extract, which did not absorb this radiation, prevented the formation of ROS by HaCaT cells. Astaxanthin showed a tendency to protect the cell against the formation of ROS induced by UVA radiation (Figure 5B). 


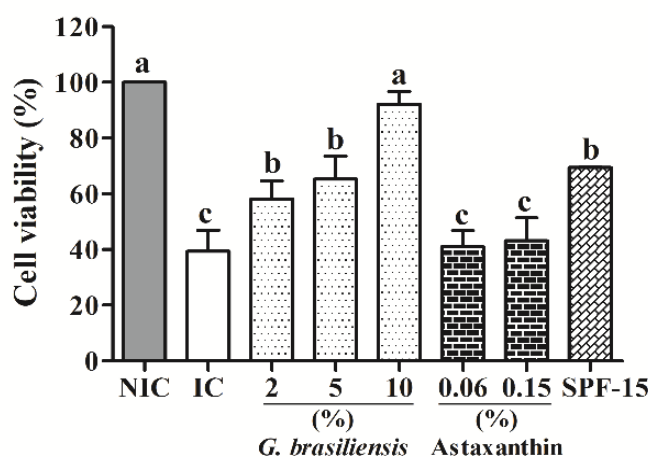

G. brasiliensis Astaxanthin

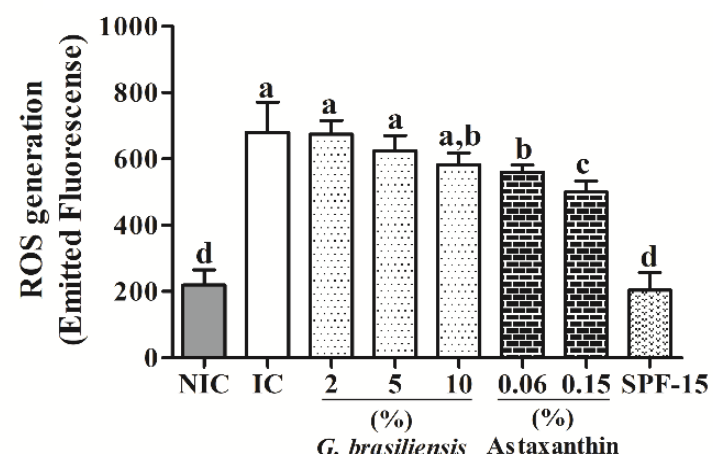

G. brasiliensis Astaxanthin

Figure 5. Evaluation of selectivity of in vitro assays: (A) Determination of cell viability as measured by the resazurin dye assay after exposure of $L 929$ fibroblasts cells to $0.5 \mathrm{~J} / \mathrm{cm}^{2}$ of UVB radiation. (B) Quantification of the formation of reactive oxygen species (ROS) in HaCaT keratinocyte cells measured using the $\mathrm{DCFH}_{2}$-DA fluorescent probe after exposure to $20.0 \mathrm{~J} / \mathrm{cm}^{2}$ of UVA radiation. Both cell types (L929 and $\mathrm{HaCaT}$ ) were protected with the extract of Garcinia brasiliensis at concentrations of 2\%, 5\% and $10 \%$ and with astaxanthin at the $0.06 \%$ and $0.15 \%$ concentrations. NIC corresponds to the nonirradiated control (cells not exposed to UV radiation and not protected with extracts of Garcinia brasiliensis and astaxanthin). IC = irradiated control (cells exposed to UV radiation and not protected with extracts of Garcinia brasiliensis and astaxanthin). Different letters indicate that there was a statistically significant difference after analysis by the one-way ANOVA test followed by the Tukey test for multiple comparisons $(p<0.05)$.

This validation shows that cell viability and ROS generation are models that allow researchers to evaluate the photoprotective ability of compounds when exposed to UVB and UVA radiation, respectively.

The inter-day precision was established based on the repeatability of the evaluations of cell viability, lipid peroxidation and ROS formation, using sunscreens brands A and B over 3 days. The novel in vitro assays were considered precise on the basis that the ranges of the coefficients of variation were between $1.7 \%$ to $8.4 \%$.

Therefore, our data showed that cell parameters, such as cell viability and lipid peroxidation, undergo dose-dependent changes only when exposed to UVB rays (reduction from 3.15 to $95.4 \%$ in the number of viable cells, and increase of 1.2 to $42.7 \mathrm{nM} \mathrm{MDA} / \mathrm{pg}$ of lipid peroxide protein). After treating the 1929 strain with sunscreens, these tests helped us to verify the distinction of efficacy of products with different protection factors and brands. The oxidative stress parameter (ROS formation) is dose-dependent only for UVA rays and, therefore, allowed to evaluate the effectiveness of photoprotective formulations (with different protection factors and brands) exposed to UVA radiation.

The assays described in this study helped us to predict the photoprotective potential of anti-solar and natural products contributing as in vitro alternatives to be applied in the research and development of new products. Thus, the establishment of these in vitro tests represents an important step for public health due to the importance of developing effective and safe sunscreens.

\section{ACKNOWLEDGMENTS}

The authors would like to thank Prof. Dr. Marcelo Henrique dos Santos (Federal University of Viçosa - MG, Brazil) for providing the extract of Garcinia brasiliensis and to Dr. Taís Aleriana Lucon Wagemaker (Director of R\&D, G\&G Cosmética LTDA, Ribeirão Preto - SP) for his contribution to the statistical analysis of the data and scientific advice. 


\section{REFERENCES}

1. Figueiredo SA, Moraes D, Vilela FMP, Faria AN, Santos MH, Fonseca MJV. A novel research model for evaluating sunscreen protection in the UV-A1. J Photochem Photobiol B. 2018;178:61-8. http://dx.doi.org/10.1016/j.jphotobiol.2017.10.031. PMid:29112891.

2. Schuch AP, Moraes MCS, Yagura T, Menck CFM. Highly sensitive biological assay for determining the photoprotective efficacy of sunscreen. Environ Sci Technol. 2014;48(19):11584-90. http://dx.doi.org/10.1021/es503721a. PMid:25216262.

3. Yeager DG, Lim HW. What's new in photoprotection: a review of new concepts and controversies. Dermatol Clin. 2019;37(2):149-57. http://dx.doi.org/10.1016/j.det.2018.11.003. PMid:30850037.

4. Saucedo GMG, Vallejo RS, Giménez JCM. Effects of solar radiation and an update on photoprotection. Ann Pediatr [Internet]. 2020 [cited 2020 June 18];92(6):e1-377.e9. Available from: http://creativecommons.org/licenses/by-nc-nd/4.0/

5. Oliveira DN, Delafiori J, Ferreira MS, Catharino RR. In vitro evaluation of Sun Protection Factor and stability of commercial sunscreens using mass spectrometry. J Chromatogr B Analyt Technol Biomed Life Sci. 2015;988:13-9. http://dx.doi.org/10.1016/j.jchromb.2015.02.018. PMid:25743700.

6. Petersen B, Wulf HC. Application of sunscreen: theory and reality. Photodermatol Photoimmunol Photomed. 2014;30(2-3):96-101. http://dx.doi.org/10.1111/phpp.12099. PMid:24313722.

7. Schneider G, Figueroa FL, Vega J, Chaves P, Álvarez-Gómez F, Korbee N, Bonomi-Barufi J. Photoprotection properties of marine photosynthetic organisms grow in high ultraviolet exposure areas: cosmeceutical applications. Algal Res. 2020;49:101956. http://dx.doi.org/10.1016/j.algal.2020.101956.

8. Sun S, Jiang P, Su W, Xiang Y, Li J, Zeng L, Yang S. Wild chrysanthemum extract prevents UVB radiation-induced acute cell death and photoaging. Cytotechnology. 2016;68(2):229-40. http://dx.doi.org/10.1007/s10616-014-9773-5. PMid:25052044.

9. Kockler J, Oelgemöller M, Robertson S, Glass BD. Photostability of sunscreens. J Photochem Photobiol Photochem Rev. 2012;13(1):91-110. http://dx.doi.org/10.1016/j.jphotochemrev.2011.12.001.

10. More BD. Physical sunscreens: on the comeback trail. Indian J Dermatol Venereol Leprol. 2007;73(2):80-5. http://dx.doi.org/10.4103/0378-6323.31890. PMid:17456911.

11. Hibbert SA, Costello P, O'Connor C, Bell M, Griffiths CEM, Watson REB, Sherratt MJ. A new in vitro assay to test UVR protection of dermal extracellular matrix components by a flat spectrum sunscreen. J Photochem Photobiol B. 2017;175:58-64. http://dx.doi.org/10.1016/j.jphotobiol.2017.08.020. PMid:28846936.

12. Marionnet C, Pierrard C, Golebiewski C, Bernerd F. Diversity of biological effects induced by longvware UVA rays (UVA1) in reconstructed skin. PLoS One. 2014;9(8):e105263. http://dx.doi.org/10.1371/journal.pone.0105263. PMid:25140898.

13. Moyal DD, Fourtanier AM. Efficacy of broad-spectrum sunscreens against the suppression of elicitation of delayed-type hypersensitivity responses in humans depends on the level of ultraviolet A protection. Exp Dermatol. 2003;12(2):153-9. http://dx.doi.org/10.1034/j.1600-0625.2003.00020.x. PMid:12702143.

14. Pelizzo M, Zattra E, Nicolosi P, Peserico A, Garoli D, Alaibac M. In vitro evaluation of sunscreens: an update for the clinicians. Int Sch Res Notices Dermatol. 2012;2012:352135. http://dx.doi.org/10.5402/2012/352135. PMid:23227355.

15. Dai J, Ma H, Fan J, Li Y, Wang J, Ni H, Xia G, Chen S. Crude polysaccharide from an anti-UVB cell clone of Bupleurum scorzonerifolium protect HaCaT cells against UVB-induced oxidative stress. Cytotechnology. 2011;63(6):599-607. http://dx.doi.org/10.1007/s10616-011-9381-6. PMid:21948115.

16. Fourtanier A, Bernerd F, Bouillon C, Marrot L, Moyal D, Seité S. Protection of skin biological targets by different types of sunscreens. Photodermatol Photoimmunol Photomed. 2006;22(1):22-32. http://dx.doi.org/10.1111/j.1600-0781.2006.00188.x. PMid:16436178.

17. Vilela FMP, Oliveira FM, Vicentini FTMC, Casagrande R, Verri WA Jr, Cunha TM, Fonseca MJV. Commercial sunscreen formulations: UVB irradiation stability and effect on UVB irradiationinduced skin oxidative stress and inflammation. J Photochem Photobiol B. 2016;163:413-20. http://dx.doi.org/10.1016/j.jphotobiol.2016.09.007. PMid:27627683. 
18. Chisvert A, Tarazona I, Salvador A. A reliable and environmentally-friendly liquid-chromatographic method for multi-class determination of fat-soluble UV filters in cosmetic products. Anal Chim Acta. 2013;790:61-7. http://dx.doi.org/10.1016/j.aca.2013.06.032. PMid:23870410.

19. Biesalski HK, Berneburg M, Grune T, Kerscher M, Krutmann J, Raab W, Reimann J, Reuther T, Robert L, Schwarz T. Hohenheimer Consensus Talk: oxidative and premature skin ageing. Exp Dermatol. 2003;12(Suppl 3):3-15. http://dx.doi.org/10.1111/j.0906-6705.2003.00148.x. PMid:15015895.

20. Figueiredo SA, Vilela FMP, Silva CA, Cunha TM, Santos MH, Fonseca MJV. In vitro and in vivo photoprotective/photochemopreventive potential of Garcinia brasiliensis epicarp extract. J Photochem Photobiol B. 2014;131:65-73. http://dx.doi.org/10.1016/j.jphotobiol.2014.01.004. PMid:24491421.

21. Vielhaber G, Grether-Beck S, Koch O, Johncock W, Krutmann J. Sunscreens with an absorption maximum of $\geq 360 \mathrm{~nm}$ provide optimal protection against UVA1-induced expression of matrix metalloproteinase-1, interleukin-1, and interleukin-6 in human dermal fibroblasts. Photochem Photobiol Sci. 2006;5(3):275-82. http://dx.doi.org/10.1039/b516702g. PMid:16520862.

22. Kuete V, Sandjo LP, Wiench B, Efferth T. Cytotoxicity and modes of action of four Cameroonian dietary spices ethno-medically used to treat Cancers: Echinopsgiganteus, Xylopiaaethiopica, Imperatacylindrica and Piper capense. J Ethnopharmacol. 2013;149(1):245-53. http://dx.doi.org/10.1016/j.jep.2013.06.029. PMid:23827757.

23. Bradford MM. A rapid and sensitive method for the quantitation of microgram quantities of protein utilizing the principle of protein-dye binding. Anal Biochem. 1976;72(1-2):248-54. http://dx.doi.org/10.1016/0003-2697(76)90527-3. PMid:942051.

24. Morlière P, Moysan A, Santus R, Hüppe G, Mazière JC, Dubertret L. UVA-induced lipid peroxidation in cultured human fibroblasts. Biochim Biophys Acta. 1991;1084(3):261-8. http://dx.doi.org/10.1016/0005-2760(91)90068-S. PMid:1888774.

25. Zeng J, Bi B, Chen L, Yang P, Guo Y, Zhou Y, Liu T. Repeated exposure of mouse dermal fibroblasts at a sub-cytotoxic dose of UVB leads to premature senescence: a robust model of cellular photoaging. J Dermatol Sci. 2014;73(1):49-56. http://dx.doi.org/10.1016/j.jdermsci.2013.08.013. PMid:24054498.

26. Wang $\mathrm{H}$, Joseph JA. Quantifying cellular oxidative stress by dichlorofluorescein assay using microplate reader. Free Radic Biol Med. 1999;27(5-6):612-6. http://dx.doi.org/10.1016/S0891 5849(99)00107-0. PMid:10490282.

27. International Council for Harmonisation - ICH . Validation of analytical procedures: text and methodology Q2 (R1) [Internet]. 2005. [cited 2020 June 18]. Available from:

http://www.ich.org/products/guidelines/quality/quality-single/article/validation-of-analyticalprocedures-text-and-methodology.html

28. Sabater-Tobella J, Vilumara-Torrallardona A. Buenas prácticas de laboratorio (GLP). Madrid: Díaz de Santos; 1988.

29. Moreta C, Tena MT. Determination of UV filters in packaging by focused ultrasonic solid-liquid extraction and liquid chromatography. J Chromatogr A. 2011;1218(21):3392-9. http://dx.doi.org/10.1016/j.chroma.2010.11.087. PMid:21185027.

30. Vioux-Chagnoleau C, Lejeune F, Sok J, Pierrard C, Marionnet C, Bernerd F. Reconstructed human skin: from photodamage to sunscreen photoprotection and anti-aging molecules. J Dermatol Sci. 2006;2:S1-12. http://dx.doi.org/10.1016/j.descs.2006.08.001.

31. Wang Y-S, Zhou S-S, Shen C-Y, Jiang J-G. Isolation and identification of four antioxidants from Rhodiola crenulata and evaluation of their UV photoprotection capacity in vitro. J Funct Foods. 2020;66:103825. http://dx.doi.org/10.1016/j.jff.2020.103825.

32. Boncler M, Różalski M, Krajewska U, Podsędek A, Watala C. Comparison of PrestoBlue and MTT assays of cellular viability in the assessment of anti-proliferative effects of plant extracts on human endothelial cells. J Pharmacol Toxicol Methods. 2014;69(1):9-16. http://dx.doi.org/10.1016/j.vascn.2013.09.003. PMid:24103906.

33. Battie C, Jitsukawa S, Bernerd F, Del Bino S, Marionnet C, Verschoore M. New insights in photoaging, UVA induced damage and skin types. Exp Dermatol. 2014;23(Suppl 1):7-12. http://dx.doi.org/10.1111/exd.12388. PMid:25234829. 
34. Gęgotek A, Biernacki M, Ambrożewicz E, Surażyński A, Wroński A, Skrzydlewska E. The cross-talk between electrophiles, antioxidant defence and the endocannabinoid system in fibroblasts and keratinocytes after UVA and UVB irradiation. J Dermatol Sci. 2016;81(2):107-17. http://dx.doi.org/10.1016/j.jdermsci.2015.11.005. PMid:26674123.

35. Cole C, Appa Y, Ou-Yang H. A broad spectrum high-SPF photostable sunscreen with a high UVA-PF can protect against cellular damage at high UV exposure doses. Photodermatol Photoimmunol Photomed. 2014;30(4):212-9. http://dx.doi.org/10.1111/phpp.12124. PMid:24806442.

36. Faroux JM, Ureta MM, Tymczyszyn EE, Gómez-Zavaglia A. An overview of peroxidation reactions using liposomes as model systems and analytical methods as monitoring tools. Colloids Surf B Biointerfaces. 2020;195:111254. http://dx.doi.org/10.1016/j.colsurfb.2020.111254. PMid:32679444.

37. Nicolson GL, Ash ME. Lipid replacement therapy: a natural medicine approach to replacing damaged lipids in cellular membranes and organelles and restoring function. Biochim Biophys Acta. 2014;1838(6):1657-79. http://dx.doi.org/10.1016/j.bbamem.2013.11.010. PMid:24269541.

38. Cole C. Sunscrens: what is the ideal testing model? Photodermatol Photoimmunol Photomed. 2014;30(2-3):81-7. http://dx.doi.org/10.1111/phpp.12095. PMid:24313596.

39. Che DN, Xie GH, Cho BO, Shin JY, Kang HJ, Jang SI. Protective effects of grape stem extract against UVB-induced damage in C57BL mice skin. J Photochem Photobiol B. 2017;173:551-9. http://dx.doi.org/10.1016/j.jphotobiol.2017.06.042. PMid:28697472.

40. Duryee MJ, Klassen LW, Schaffert CS, Tuma DJ, Hunter CD, Garvin RP, Anderson DR, Thiele GM. Malondialdehyde-acetaldehyde adduct is the dominant epitope after MDA modification of proteins in atherosclerosis. Free Radic Biol Med. 2010;49(10):1480-6. http://dx.doi.org/10.1016/j.freeradbiomed.2010.08.001. PMid:20696236.

41. Feng J, Chen Y, Pu J, Yang X, Zhang C, Zhu S, Zhao Y, Yuan Y, Yuan H, Liao F. An improved malachite green assay of phosphate: mechanism and application. Anal Biochem. 2011;409(1):144-9. http://dx.doi.org/10.1016/j.ab.2010.10.025. PMid:20971056.

42. Singh $M$, Kapoor A, Bhatnagar A. Oxidative and reductive metabolism of lipid-peroxidation derived carbonyls. Chem Biol Interact. 2015;234:261-73. http://dx.doi.org/10.1016/j.cbi.2014.12.028. PMid:25559856.

43. Karthikeyan R, Kanimozhi G, Prasad NR, Agilan B, Ganesan M, Mohana S, Srithar G. 7Hydroxycoumarin prevents UVB-induced activation of NF-kB and subsequent overexpression of matrix metalloproteinases and inflammatory markers in human dermal fibroblast cells. J Photochem Photobiol B. 2016;161:170-6. http://dx.doi.org/10.1016/j.jphotobiol.2016.04.027. PMid:27240190.

44. Lowe NJ. An overview of ultraviolet radiation, sunscreens, and photo-induced dermatoses. Dermatol Clin. 2006;24(1):9-17. http://dx.doi.org/10.1016/j.det.2005.08.001. PMid:16311163.

45. Couteau C, Faure A, Fortin J, Paparis E, Coiffard LJM. Study of the photostability of 18 sunscreens in creams by measuring the SPF in vitro. J Pharm Biomed Anal. 2007;44(1):270-3. http://dx.doi.org/10.1016/j.jpba.2007.01.052. PMid:17367977.

46. Narang AS, Mantri RV, Raghavan KS. Excipient compatibility and functionality. In Qiu Y, Chen Y, Zhang GGZ, Yu L, Mantri RV, editors. Developing solid oral dosage forms. 2nd ed. London: Academic Press; 2017. p. 151-179. https://doi.org/10.1016/B978-0-12-802447-8.00006-6.

47. Alves CQ, David JM, David JP, Bahia MV, Aguiar RM. Métodos para determinação de atividade antioxidante in vitro em substratos orgânicos. Quim Nova. 2010;33(10):2202-10. http://dx.doi.org/10.1590/S0100-40422010001000033.

48. Portugal-Cohen M, Afriat-Staloff I, Soroka Y, Frusic-Zlotkin M, Schlippe G, Voss W, Ma'or Z. Protective effects of a novel preparation consists of concentrated dead sea water and natural plants extracts against photo-damage. J Cosmet Dermatol Sci Appl. 2014;4:7-15. http://dx.doi.org/10.4236/jcdsa.2014.41002.

49. Zanchetta LM, Kirk D, Lyng F, Walsh J, Murphy JEJ. Cell-density-dependent changes in mitochondrial membrane potential and reactive oxygen species production in human skin cells post sunlight exposure. Photodermatol Photoimmunol Photomed. 2010;26(6):311-7. http://dx.doi.org/10.1111/j.1600-0781.2010.00551.x. PMid:21091789. 
50. Chen X, Zhong Z, Xu Z, Chen L, Wang Y. 2',7'-Dichlorodihydrofluorescein as a fluorescent probe for reactive oxygen species measurement: forty years of application and controversy. Free Radic Res. 2010;44(6):587-604. http://dx.doi.org/10.3109/10715761003709802. PMid:20370560.

51. Tarpey M, Fridovich I. Methods of detection of vascular reactive species nitric oxide, superoxide, hydrogen peroxide, and peroxynitrite. Circ Res. 2001;89(3):224-36.

http://dx.doi.org/10.1161/hh1501.094365. PMid:11485972.

\section{Authors' contributions}

SAF and TNA performed the experiments and collected the data; MJVF designed the study; SAF, FMPV, ANF and MJVF analysis and evaluation of data and wrote the paper. 